\title{
Prehistorically Nigella Sativa is being used to treat Inflammation, High Plasma Lipids, High Blood Pressure, Asthma, Diabetes Mellitus and Arthritis
}

\author{
Shah Murad Mastoi ${ }^{1 *}$, Moosa Khan ${ }^{2}$, Seema Shah Murad ${ }^{3}$, Farid-Ud-Din ${ }^{4}$, Abdul Ghaffar ${ }^{5}$ Jamila Shah $^{6}$ and \\ Manal Rauf Mahar ${ }^{7}$
}

${ }^{1}$ Department of Pharmacology, Pakistan

${ }^{2}$ Department of Therapeutics and Pharmacology, Pakistan

${ }^{3}$ Department of Gynecology, Pakistan

${ }^{4}$ Department of Pharmacology, Pakistan

${ }^{5}$ CWO, IMDC, DANTH, Pakistan

${ }^{6}$ Department of Psychology, Pakistan

${ }^{7}$ Department of Dentistry, Pakistan

Submission: December 31, 2019; Published: February 24, 2020

*Corresponding author: Weicheng Cui, School of Engineering, Westlake University, Hangzhou, China

\begin{abstract}
Allopathic drugs used as hypolipidemic agents have number of unwanted effects. Herbal therapy for Hyperlipidemia is getting attention due to their less frequent side effects. In this study we have compared hypolipidemic effects of Fenofibrate 40mg with Nigella sativa. Seventyfive hyperlipidemic patients from National Hospital Lahore were enrolled for study. Consent was taken from all enrolled participants and were divided in three equal numbers i.e.; twenty-five in each group. Group 1 was on Nigella sativa, group 2 was on Gemfibrozil and third group was on placebo therapy. They were advised to take drugs for two months. After completion of study pretreatment and post treatment values of LDL cholesterol were analyzed statistically. In 25 patients who were on Nigella sativa, their LDL cholesterol decreased from $191.14 \pm 3.45$ to $159.40 \pm 2.98 \mathrm{mg} / \mathrm{dl} .31 .7 \mathrm{mg} / \mathrm{dl}$ LDL reduction was observed when compared with placebo group. In 25 patients who were on Fenofibrate $40 \mathrm{mg}$, their LDL cholesterol decreased from $197.77 \pm 3.91 \mathrm{mg} / \mathrm{dl}$ to $159.62 \pm 2.20 \mathrm{mg} / \mathrm{dl}$. LDL reduction in this group was $38.2 \mathrm{mg} / \mathrm{dl}$. These changes are highly significant with p-values of $<0.001$. We concluded from this study that hypolipidemic characteristic of Nigella sativa is comparable and therapeutically as effective as traditionally used hypolipidemic medication Fenofibrate.
\end{abstract}

Keywords: Free radicals; Cardiac arrest; Allopathic drugs; Arthritis

\section{Introduction}

In human body free radicals are formed in consequence of various metabolic processes. If there is abundance of low-density lipoprotein particles in plasma, there are chances of risk to develop CAD (coronary artery disease) when free radicals interact with LDL particles. CAD may lead to morbidity and mortality due to cardiac arrest in human population [1-3]. In some cases, atherosclerotic plaques may totally block the blood supply to the myocytes, causing cardiac attack [4]. Atherosclerotic plaque contains calcium, cholesterol, free fatty acids, and macrophages in variable amount. These plaques are of two types i.e.; hard and soft. Soft plaques are more vulnerable than hard and can rupture easily as compared to hard one. There are risks for ischemic stroke too if blood supply to neurons ensues [5]. Hypolipidemic drugs can be used to prevent hyperlipidemia, CAD, heart arrhythmias and cardiac arrest. Allopathic drugs used to prevent, or cure Hyperlipidemia include Statins, Fibrates, niacin and bile acid binding resins [6]. If Fenofibrate is used, there is increased synthesis of high-density lipoprotein particles in plasma. In patients suffering from hyperlipidemia, Fenofibrate enhances turnover of tissue cholesterol, thus reducing lipoprotein particles. Apoproteins in LDL are also changed by Fenofibrates leading to high affinity for the low-density lipoprotein receptors to LDL particles $[7,8]$. Nigella sativa or kalonji contains conjugated linoleic acid, thymoquinone, melanthin, nigilline, damascenine, 
and trans-anethole. Thymoquinone (TQ) extracted from Nigella sativa (kalonji) inhibits iron-dependent microsomal lipid peroxidation. Stimulation of polymorphonuclear leukocytes with thymoquinone works as protector against damaging effects of free radicles generated biochemically in human body $[9,10]$. Prehistorically Nigella sativa is being used to treat, inflammation, high plasma lipids, high blood pressure, asthma, diabetes mellitus, arthritis, and gastrointestinal problems [11-14]. In this study we tried to compare hypolipidemic potential of Nigella sativa with Fenofibrate.

\section{Patients and Methods}

Design of research work: It was single blind placebocontrolled study.

Venue: The research work was conducted at National Hospital Lahore, Pakistan from February to July 2015.

Sample size and inclusion criteria: 75 hyperlipidemic patients were enrolled whose age range was from 18 to 70 years. Well explained, written consent was taken from all participants.

Exclusion criteria: Hypothyroidism, peptic ulcer, diabetes mellitus type-I and type-2, any major cardiac, renal and hepatic illness.

\section{Grouping and methodology}

Enrolled patients were divided in three equal numbers i.e.; 25 patients in Group-1, 25 in Group-2, and 25 patients in Group-3. Baseline LDL -cholesterol of all patients was determined in Biochemistry laboratory of the hospital. Separate folder was designed for each enrolled patient, in which their personal data, medical history, laboratory reports, follow up visit proforma were kept. Their plasma LDL-cholesterol was calculated by Fried Wald formula [7] (LDL-C = Total cholesterol-(Triglycerides $/ 5+$ HDL-C). 25 patients of group- 1 were advised to take eight grams of Kalonji (Nigella sativa) in two divided doses for two months. 25 patients of group- 2 were advised to use $40 \mathrm{mg}$ Fenofibrate tablets twice daily for two months. 25 patients of group-3 were advised to take Capsule (Placebo capsule containing grinded wheat powder) twice daily for two months. They were advised to take their medication after breakfast and after dinner. All participants were convinced to go for 20 minutes brisk walk at morning or evening time. Fortnight follow up visit was arranged for all participants. After two months research period their lipid profile was determined in same laboratory of the hospital.

\section{Statistical analysis}

Mean values of LDL-cholesterol \pm SEM were analyzed statistically by using SPSS 2014 version. Paired t-test was applied to analyses pre-treatment and post treatment values. $p<0.05$ was minimum probability value to determine statistical significance. $\mathrm{p}<0.05$ was considered as non-significant change in tested parameter. $p>0.001$ was marked as highly significant change in the tested parameter.

\section{Results}

When results were compiled and statistically analyzed, it was observed that Nigella sativa and Fenofibrate 40mg decreased LDL-cholesterol significantly. Nigella sativa decreased LDL cholesterol from $191.14 \pm 3.45 \mathrm{mg} / \mathrm{dl}$ to $159.40 \pm 2.98 \mathrm{mg} / \mathrm{dl}$. This change in mean values was $31.7 \mathrm{mg} / \mathrm{dl}$ with highly significant p-value of $<0.001$. Fenofibrate decreased LDL cholesterol from $197.77 \pm 3.91 \mathrm{mg} / \mathrm{dl}$ to $159.62 \pm 2.20 \mathrm{mg} / \mathrm{dl}$. In mean values this change was $38.2 \mathrm{mg} / \mathrm{dl}$ with highly significant $\mathrm{p}$-value of $<0.001$. Placebo group showed LDL cholesterol reduction from $163.10 \pm 1.45 \mathrm{mg} / \mathrm{dl}$ to $159.40 \pm 1.77 \mathrm{mg} / \mathrm{dl}$. This change in mean values was $3.7 \mathrm{mg} / \mathrm{dl}$, with non-significant $\mathrm{p}$-value of $>0.05$ (Table 1).

Table 1: Illustrating LDL-Cholesterol Values before and after Treatment with Nigella Sativa, Fenofibrate $40 \mathrm{Mg}$ and Placebo with their P-Values.

\begin{tabular}{|c|c|c|c|c|}
\hline Drug & At Day-0 & At Day-60 & Change in mg/dl & p-values \\
\hline NS & $191.14 \pm 3.45$ & $159.40 \pm 2.98$ & 31.7 & $<0.001$ \\
\hline FF & $197.77 \pm 3.91$ & $159.62 \pm 2.20$ & 38.2 & $<0.001$ \\
\hline PL & $163.10 \pm 1.45$ & $159.40 \pm 1.77$ & 3.7 & $>0.05$ \\
\hline
\end{tabular}

NS stands for Nigella sativa, FF stands for Fenofibrate, PL stands for placebo group. All parameters are measured in $\mathrm{mg} / \mathrm{dl}$, P-value $<0.01$ stands for significant change, $\mathrm{P}$-value $>0.05$ stands for non-significant change.

\section{Discussion}

Normal plasma lipid levels are required to keep heart healthy. Statins, Fibrates, Bile Acid Binding Resins, and Niacin (Vitamin B3) are used as hypolipidemic medicines in allopathy, but all these have unwanted effects. In Ayurveda discipline of therapeutics, various herbs, fruits and vegetables are used to reduce bad-cholesterol (LDL-C) and to increase good-cholesterol (HDL-C). In various research study results Kalonji is labeled as hypolipidemic therapeutic agent but little research work is done on comparison of its hypolipidemic potential with allopathy related hypolipidemic medicines. This research was targeted to compare its hypolipidemic characteristics with one of the Fibrate i.e. Fenofibrate $40 \mathrm{mg}$. In our results it was observed that Kalonji or Nigella sativa reduced LDL-cholesterol $31.7 \mathrm{mg} / \mathrm{dl}$ which is almost $16.58 \%$ reduction in the parameter. This change is highly significant $(p<0.001)$. Same highly significant change $(p<0.001)$ was observed by using Fenofibrate $40 \mathrm{mg}$ in 25 hyperlipidemic patients. Results of study conducted by Osenda M, et al. [15] also support our observation and results. Fandelaki I, et al. [16] observed that Kalonji increase HDL-cholesterol, and decrease LDLcholesterol, triglycerides, and plasma total cholesterol in 4 weeks therapy if brisk walk is added with this medication. Alberti $\mathrm{K}$, et al. [17] stated that there are various mechanisms by which seeds of the herb decrease LDL-cholesterol and decrease triglycerides. Duverger A, et al. [18] explained that NS inhibit enterohepatic circulation, leading to decreased synthesis of cholesterol by HMGCoA reductase pathway. Harnandez M, et al. [19] observed lesser hypolipidemic effects of Kalonji when used in 15 hyperlipidemic 
patients for two weeks. They recommended to use herb for prolonged time as lipoproteins and their structural apoproteins take time to be synthetize in hepatic cells. Harnandez M, et al. [20] had explained that kalonji is useful for increasing HDL-cholesterol. Haddad P, et al. [21] wrote in their article that kalonji decrease plasma TG (triglycerides) rich lipoproteins (VLDL), thus neutral fat is reduced. Exchange of neutral fats between high density lipoproteins and very low-density lipoproteins in plasma occurs by use of Kalonji [22].

\section{References}

1. Akazawa A, Nishikawa K, Suzuki K, et al. (2002) Induction of apoptosis in a human breast cancer cell overexpressing RrbB-2 receptor by alpha-tocopheryloxybutyric acid. Jpn J Pharmacol 89: 417-421.

2. Salganik RI (2001) The benefits and hazards of antioxidants: controlling apoptosis and other protective mechanisms in cancer patients and the human population. J Am Coll Nutr 20(5): 464-472.

3. Chugh SS, Reinier K, Teodorescu C, Evanado A, Kehr E, et al. (2008) Epidemiology of sudden cardiac death: Clinical and research implications. Prog Cardiovas Dis 51(3): 213-228.

4. Bardy GH, Lee KL, Mark DB, Poole JE, Toff WD, et al. (2008) Home use of automated external defibrillators for sudden cardiac arrest. N Engl J Med 358(17): 793-804.

5. Kathryn M, Frederick S, Edward F (2013) Macrophages in atherosclerosis: a dynamic balance. Nat Rev Immunol 13(10): 709-721.

6. Pan SY, Dong H, Guo BF, Zhang Y, Yu ZL, et al. (2011) Effective kinetics of schisandrin B on serum/hepatic triglyceride and cholesterol levels in mice with and without influence of fenofibrate. NaunynSchmiedeberg's, Archieves of Pharmacology 383(6): 585-591.

7. Boudewijn K, Jan WFE, Manuel CC (2013) Dyslipidemia in obesity: Mechanisms and potential targets. Nutrients 5(4): 1218-1240.

8. John CM, Henry NG, Pierre A, Andreotti F, Borén J, et al. (2012) Triglycerides-rich lipoproteins and high-density lipoprotein cholesterol in patients at high risk of cardiovascular disease: evidence and guidance for management. Er Heart Jou 32(11): 1345-1361.

9. Ahmad A, Husain A, Mujeeb M, Khan SA, Najmi AK, et al. (2013) A review on therapeutic potential of Nigella sativa: A miracle herb. Asian Pac J Trop Biomed 3(5): 337-352.
10. Bourgou S, Pichette A, Marzouk B, Legault J (2012) Antioxidant, antiinflammatory, anticancer and antibacterial activities of extracts from Nigella sativa plant parts. J Food Biochem 36(5): 539-546.

11. Harzallah HJ, Grayaa R, Kharoubi W, Maaloul A, Hammami M, et al. (2012) Thymoquinone, the Nigella sativa bioactive compond, prevents circulatory oxidative stress caused by 1,2-dimethylhydrazine in erythrocyte during colon postinitiation carcinogenesis. Oxid Med Cell Longev, pp. 8540-8565.

12. Kanter M, Akpoolat M, Aktas C (2009) Protective effects of the volatile oil of Nigella stiva seeds on bet acell damage in streotocin-induced diabetic rats: a light and electron microscopic study. J Mol Histol 40(56): 379-385.

13. Benhaddou AA, Martineau L, Vuong T, Meddah B, Madiraju P, et al. (2011) The in vivi antidiabetic activity of Nigella stiva mediated through activation of the AMPK pathway and increase muscle glut4 content. Evid Based Complement Alternat Med.

14. Gokce A, Oktar S, Koc A, Yonden Z (2011) Protective effects of thymoquinone against methotrexate-induced testicular injury. Human Exp Toxicol 30(8): 897-903.

15. Osende M, Jhajh S, Loraka Y, Simvan T (2013) Antioxidant Herbs. Jou Cl Nut Res 16(5): 99-104.

16. Fandelaki I, Marinah T, Mahassine N, Datau E (2013) Chinese plants and Allopathy. Indo Med Jou 102(61): 122-129.

17. Alberti K, Gunith S, Haas M, Jhajh L (2010) Statins and Fibrates: Comparison with Herbal plants. Jou Gastro Rev 7(3): 88-90.

18. Duverger A, Ismail M, Collins R, Ragheb A, Berrada Y (2010) Phytochemistry of asthetic plants. UJPR 6(3): 77-83.

19. Harnandez M, Khuwarh M, Jorge R, Barret C (2009) Antiatherogenic potential of kalonji seeds. Biochem Res 5(6): 33-38.

20. Haddad P, Setaff A, Neural C, Mahon S (2014) HMG-CoA reductase inhibitor plants. Pertanika Jou Sch Res Rev 14(6): 66-69.

21. Grundy SM, Setaff AA, Packard CU, Shephered JM (2014) Lipid lowering effects of kalonji. J Plants Res 8(6): 67-72.

22. Wong NC, Naem EE, Lordu YI, Mcdusa VE, Assi MA (2012) How do plants work in therapeutics? J Cl Micr 16(7): 89-94.

Your next submission with Juniper Publishers will reach you the below assets

- Quality Editorial service

- Swift Peer Review

- Reprints availability

- E-prints Service

- Manuscript Podcast for convenient understanding

- Global attainment for your research

- Manuscript accessibility in different formats

( Pdf, E-pub, Full Text, Audio)

- Unceasing customer service

Track the below URL for one-step submission https://juniperpublishers.com/online-submission.php 